\title{
Archival Tissue
}

National Cancer Institute

\section{Source}

National Cancer Institute. Archival Tissue. NCI Thesaurus. Code C160656.

Tissue stored in a biospecimen repository for future study use. 